\title{
Political Polarization in the Brazilian Election Campaign for the Presidency of Brazil in 2018: An Analysis of the Social Network Instagram
}

\author{
Carla Montuori Fernandes ${ }^{1}$, Luiz Ademir de Oliveira ${ }^{2}$, Mariane Motta de Campos ${ }^{1} \&$ Vinícius Borges Gomes ${ }^{1}$ \\ ${ }^{1}$ Post-graduation in Communication at Universidade Paulista, São Paulo, Brazil \\ ${ }^{2}$ Post-graduation in Communication at Federal University of Juiz de Fora, Minas Gerais, Brazil \\ Correspondence: Carla Montuori Fernandes, Post-graduation in Communication at Universidade Paulista, São Paulo, \\ Brazil.
}

Received: May 6, 2020

doi:10.11114/ijsss.v8i4.4837
Accepted: June 5, $2020 \quad$ Available online: June 11, 2020

URL: https://doi.org/10.11114/ijsss.v8i4.4837

\begin{abstract}
The 2018 elections in Brazil were marked by major changes in the country's political and social scenario. The present work focuses on the study of the campaigns of Fernando Haddad (PT) and Jair Bolsonaro (PSL) on Instagram during the second round. Thus, through Content Analysis (Bardin, 2011) and theoretical discussion regarding political polarization and electoral communication, the work proposes to understand how the campaigns of both candidates took place and which strategies were recurrent in a scenario of political crisis and reorganization, not only in a communicational field, but also in a political field.
\end{abstract}

Keywords: communication, polarization, elections 2018, social networks, Instagram

\section{Introduction: Political Tensioning in Brazil and the 2018 Elections}

\subsection{Introduce the Problem}

Political facts implicate in communicational variants. The overlay in these fields is a phenomena not only accentuated by the development of the media, but is inherent to them. However, the prevalence of a communicational scenario as an essential space for politics and the disputes for power make mediatic spaces a sort of modern agoras to understand the development of politics.

The Brazilian presidential elections, held in 2018, were marked by several unusual facts since the country's re-democratization. The first of which is, for the first time since 1994, the Party of Brazilian Social Democracy (PSDB) did not occupy one of the top positions in the dispute. In 1994 and 1998 elections PSDB won in the first round, with the victory of Fernando Henrique Cardoso, leaving PT on the second place. At the disputes of 2002, 2006, 2010 and 2014, the political party lost to PT in the second round. Polarizing the competition with the Workers Party (PT) since then, PSDB has lost the lead of the right-wing field of politics and had its candidate, Geraldo Alckmin, only reaching the fourth position in the plead

The man who disputed the second round with PT - and won - was Jair Bolsonaro, candidate by the small Social Liberal Party (PSL). Outside the party, the candidate did not quite have a strong coalition, nor great support from traditional politicians. With constant presence in social networks, Bolsonaro presented himself as a candidate more independent from the known standards of politics and, through a communicational field, built his name over strong opposition to the ideology of PT Party, but also to the known political forces in Brazil. Despite being a federal congressman for over 30 years, the candidate showed himself as an outsider, also taking advantage from the anti-corruption discourse, which perpetrated various investigations in the Brazilian legal scope. The "Car Wash" operation was launched in 2014 and was known for a series of corruption investigations at state-owned Petrobras. The phases of the investigative process were highlighted in the media and led to the political fall of several leaders in the country.

The second round of the presidential election had PT presence with Fernando Haddad as candidate. Bolsonaro's opponent, however, was a substitute for Lula, who was kept from applying due to the Clean Record Law, since the court has upheld a conviction in the "Guarujá Triplex" lawsuit. The former president was convicted of passive corruption 
and money laundering, accused of receiving benefit from the construction company OAS for the purchase and renovation of the building on the coast of São Paulo. This fact did not take Lula out of the symbolic race, since the former president's name was widely used in the Workers Party campaign, as well as exploited in an opposite way in Bolsonaro's campaign.

The campaign of the second-round of the election turned out to show a shocking narrative which was both very intense and based on attacks. Although the anti-system narrative was the emphasis of the winning campaign, a traditional party was the center of many debates. Such fact paradoxically imposed an ideological debate in the context and revealed more objective positionings regarding the comprehension of left and right.

Though these concepts may vary, what arouse the interest of this work is how they were set up in a way to build polarized narratives in the elections. Polarization highlights two distinct points and a clear and objective confrontation, not only by the context of the dual dispute, but also by the favorable political context.

To this end, the article resumes the publications of Bolsonaro and Haddad on Instagram, in the second-round of the 2018 elections, in order to answer whether there was, in fact, the polarization narrative and, still, how it happened and under which parameters. Thus, the survey clipping refers to the period of the second round that runs from 8 to 27 October.

This hypothesis is based on the perception that the country's political context, in conjunction with the circularity of and the higher engagement of voters with the media - especially given the possibility to share and produce content -, reflects a scenario of heightened political-ideological polarization. Thus, from the perspective of communicative aspects, it is possible to make certain inferences about the field of politics - itself reconfigured not only by the logic of the media, but also by recent events in Brazil, which have led to the emergence of a new right-wing wave in strong opposition to the party that was the political epicenter for the 16 previous years: the Workers' Party (PT).

We therefore consider that the opposition to PT, translated into a rejection of the left altogether, becomes an important pillar of Brazil's right, ultimately represented by Bolsonaro. The candidate's history, tainted by remarks of racial nature and in line with the defense of Brazil's military dictatorship, enabled the more radicalized tone of the campaign. Although Brazil has a fragile party system, PT's prominence triggered a hostile narrative on the part of its adversaries (Souza, 2016; Miguel, 2019).

Such process occurs by means of Content Analysis which, through interpretation strategies, aims to widen the outlook over the role of communication in the construction of political identity in current days, as well as in what ways the networks contribute to political radicalization.

\subsection{Explore Importance of the Problem}

With the spread of the internet, social and cultural transformations began to emerge in the communicational scope, with emphasis to the possibility of content production and propagation by any user with access to the web. Lemos and Levy (2010) have determined that the most significant transformations in society caused by the advent of digital communication are related to the changes in organization and culture, which end up altering the ways through which power relations operate in the 21 st century. It is a new sociability space, with new forms of social interaction, codes and its own structures.

On the same note as Lemos and Lévy, Hjarvard (2012) explain that the means of communication have shaped new interaction patterns and the media itself gets confused with other social processes, resulting in the virtualization of social interaction. Contemporary society, in this context, is filled by the media in such a way that it cannot be considered as separate from the cultural and social institutions.

The consolidation of the web 2.0, named as the second generation of services and uses on the internet has allowed, via an integrated structure of functions and contents, to give new meaning to the role of users, who go from information consumers to content creators. It becomes relevant to highlight the reach of social media as instruments of the daily interaction sphere, where links are shared, information is distributed and consumed on a global scale. In face of the possibility of building a narrative which expresses the interests of various social agents, digital media was rapidly appointed to movements of social, political and partisan nature.

In contrast to traditional media, the internet has enabled communication directed from politicians to citizens, simplifying administrative processes, expanding action with voters by promoting personalized campaigns and a new type of civic engagement (Iasulaitis \& Nebot, 2013). It is important to highlight that the use of digital technology in election periods has gained a spotlight in academic research, especially due to the aggravation of polarization enabled by this environment. To Levitsky and Ziblatt (2018), the strong feeling of polarization, especially when gaining personalist outlines, tends to be unfavorable for democracy. The authors (2018) use the United States' politics 
(Republicans X Democrats) and the election of Donald Trump, in 2016, to highlight how extreme polarization strengthens anti-system discourses and undermine democracy.

Polarization can destroy democratic norms. When socioeconomic, racial and religious differences give rise to extreme sectarianism, situation in which societies are divided into political fields whose worldviews are not only different, but mutually exclusive, it becomes difficult to sustain tolerance. Some polarization is healthy - even necessary - for democracy. (...) However, when societies divide so deeply and their parties are linked to incompatible worldviews, and especially when its members are so segregated that they rarely interact, stable party rivalries give way to perceptions of mutual threat. As tolerance disappears, politicians are increasingly tempted to abandon the institutional reserve and try to win at any cost. This may spur the rise of anti-system groups with total rejection of democratic rules. When this happens, democracy is in trouble (Levitsky and Ziblatt, 2018, p.132).

Continuing with the Brazilian case, from 2014, with the polarized election between Dilma Rousseff (PT) and Aécio Neves (PSDB), which culminated in the impeachment of the Workers Party representative in 2016, the country started to undergo strong ideological polarization, with the anti-PT movement as one of the pillars of the conflict. Since 2013 June Journeys, Brazil has been dividing and the right kept gaining space until winning the 2018 elections. As we will see in the analysis of the candidates during campaign, the dispute left the field of ideas and became a space for exchanging insults and offences.

We must also highlight that intense access to the internet seen during the elections established what Verón (1997) and Cárlon (2016) titled as hypermediatization (Verón, 1997; Cárlon, 2016) of political campaigns. Hypermedia campaigns are developed with digital media and occur through advertisements distributed via network, for a selected audience that not only consumes but also produces and disseminates political content (Howard, 2006; Ituassu et al., 2018). In Brazil, Braga and Carlomagno (2018) reiterate the political use of social networks and attest to their greater intensity during the last election campaigns. The survey released by Datafolha in the 2018 presidential elections showed that $68 \%$ of voters have access to some social network (Facebook, Instagram, Twitter, Whatsapp, etc.), and the rates of higher incidence are in young people, with 93\% in the richest and educated, with 94\% and 92\% respectively (Datafolha, 2018).

With the popularization of the Internet, already in 2009, Brazilian electoral legislation authorized, through the regulation of Law no. 12.034/09, the use of digital tools during the campaigns, making way to the consolidation of a new communication channel between parties, candidates and voters. But it was in the 2014, 2016 and 2018 elections that the exaggerated use of the internet and social media was detected as an instrument of propaganda by candidates (Braga and Carlomagno, 2018). In 2018 elections, Law 9,504/97, issued by National Congress in 2017, allowed paid posts to be showed on Facebook and Instagram platforms (content boosting), event that expanded the reach of campaigns carried out on digital social networks. To have an idea of that dimension, in the first-round of 2018 presidential elections, according to a survey released by FGV DAPP, candidate João Amoêdo was the fastest growing candidate on Instagram during the first month of campaigning (between August 14 and September 13), going from 136,300 to 452,500 followers. Regardless, Bolsonaro was the one who accumulated the most followers during the period, adding up to 2.6 million during the same period. Ciro Gomes occupied third place with 312,400 followers, followed by Haddad, which reached 230,300, with a 120\% increase in his base (Social Medias, 2018).

The social network Instagram, launched in October 2010, for exclusive use of image posting, as well as sharing, commenting and interacting, has made significant advances on the platform and in 2016 became the favorite social network of various types of celebrities, including politicians, due the possibility of making small live appearances, such as 60-second lives. Similarly to the possibility of publishing short videos of up to 60 seconds or of using IGTV, which allows users to publish longer videos, it is also possible to use stories, which are temporary publications offering several resources that allow users a higher degree of interactivity with their followers as they publish their daily errands. Posts can be shared on other social networks at the same time, such as Facebook.

Nowadays, the social network has reached 1 billion active users, second only to Facebook. According to a survey by Statista and to social network monitoring platforms, such as We Are Social, Hootsuite, and Data Reportal, in April 2020, Brazil was the second country with most Instagram users in the world, with a total of 66 million (Exame, 2019).

As social networks are used more during election campaigns not only in Brazil but around the world, understanding how political figures use them, either during elections or during their time in power, contributes to the academic environment. On his Instagram profile, Jair Bolsonaro has around 16.4mi followers, reaching, on average, 100k likes per post. Meanwhile, his adversary in the 2018 elections, Fernando Haddad, currently has $1.8 \mathrm{mi}$ followers and each of his posts gets 20-30k likes depending on the day.

This paper focuses on Instagram not only because it is an ever-growing platform, but also because of its relevance in terms of follower engagement. Our research does not, however, ignore the relevance of other social networks, such as Twitter and Facebook. This analysis offers a particular framing of the diffuse electoral scenario that privileges an 
expressive social network in which its content has been less studied than that of other networks during Brazil's last national elections.

\section{The Political Communication and the Electoral Context}

Studies in the field of Political Communication, according to Gomes (2004), have gone through three phases. In the 1940s, starting with studies by Lazarsfeld et. al. (cited by Wolf, 1999), the perspective was that the media - in this case, radio and newspapers - served as instruments for political groups. In this sense, studies on Hitler's use of the radio to disseminate the Nazi ideology, phenomenon studied by the Hypodermic Needle Theory or the Magic Bullet Theory (Wolf, 1999). The second phase of these studies was in the 1970s when, conversely, the media was no longer seen as an instrument but, rather, as possessing a great power of manipulation. Hence studies on the culture industry, especially based on the premises of Critical Theory and the Frankfurt School. Habermas (1984), for example, analyses the decadence of the political and public sphere, which he sees as having fallen prey to the oligopoly of media groups. Finally, Gomes (2004) highlights that the third phase began between the 1980s and the 1990s, when studies became more consistent and systematic, thus consolidating the area of Political Communication. Here, there is the confluence of two fields of knowledge - Political Science and Political Communication - in which the author sees the conception of the relation between media and politics as a symbiosis of two fields that complement each other in a tense relationship of mutual interference.

Until the beginning of the 21 st century, the internet had not yet had a great deal of impact on electoral disputes. In Brazil, television was the central arena of political clashes until 2014. Presidential elections in the post-redemocratization period $(1989,1994,1998,2002,2006,2010$, and 2014) were marked by the professionalization of campaigns and by the strategic use of mass media (TV and radio) during the free electoral broadcast airtime (in Portuguese, Horário Gratuito de Propaganda Eleitoral). In 2015, electoral law changed, which reduced free airtime from 45 to 35 days and its duration, from $25 \mathrm{~min}$ to only $10 \mathrm{~min}$. This measure minimized the presence of television in all subsequent elections, which have been marked by the hybrid use of mass and digital media. With less time on TV, many candidates looked for visibility in digital communication.

Studies on the impact of TV in elections are varied, especially since 1989. Albuquerque's work (1999) lays out a methodology that was widely used and adapted in other studies, which had been gaining some attention as they found in political TV broadcasts their preferential object for analyzing political communication. Other parameters for persuasion strategies were highlighted by Figueiredo et. al. (1998). Not only do presidential elections gain traction in these studies, but also disputes that were mostly at city-level, as observed by Oliveira (2004) in his analysis of TV campaigns from candidates running for mayor of the cities of Salvador and Belo Horizonte.

In the same line, studies on the use of the internet in politics experienced a sharp rise, especially after the 2008 US presidential elections. Gomes et. al. (2009) explains that Obama's winning campaign stood out for the multiplicity of online actions that were integrated to several communication tools, such as games, YouTube videos, Facebook actions, etc.

Lemos and Levy (2010) mention that the most significant transformations through which communication went after the rise of digital communication have to do with changes in organization and culture, which ultimately alter the ways in which power relations operate in the 21 st century. It is a new space of sociability. In the political field, this possibility of association exceeds the traditional path for the representation of politics since it eliminates intermediaries, thus enabling horizontal and direct ways to act and transform (EGLER, 2010).

Social networks have become a sophisticated alternative for political communication in light of the scope and breadth of digital connection, which transformed users into participants engaged in electoral campaigns as well as into defenders of certain political and party ideals (GOMES et. al., 2009). In this sense, in the context of elections, the use of Instagram has been turned into a space for campaigns to amplify political visibility, collect new followers, present projects, as well as a space for accountability to mitigate criticism to the ways in which mandates unroll (HOLLANDA and JESUS, 2018).

It is important to highlight that, even though TV has lost space in Brazil as social networks become more relevant, it is not realistic to point out one single space as the most influential. Television still has its role, especially in journalism and its coverage. Looking at Instagram is a perspective into the electoral kaleidoscope, itself ever more complex in a process of new circularities of information, as confirmed by studies on mediatization (GIBSON, 2015 cited by BRAGA and CARLOMAGNO, 2018).

\section{Method}

The Content Analysis is proposed to establish the analysis of Instagram profiles of candidates Jair Bolsonaro (PSL) and Fernando Haddad (PT). Based on the work of Bardin (2011), the analysis aims to elucidate interpretations and 
inferences from data collection and the proposal for categorization that meets the central question of the article: understand what the polarization aspects are and how they are articulated in the campaign of the second round of the Brazilian presidential elections in 2018.

The paper seeks to categorize posts based on their content and not on form, since Instagram provides different types of posts. In addition, the focus of the article was the "feed", that is, the current page of the social network, disregarding temporary publications, such as stories. This choice is made by a methodological standard that guarantees greater accuracy in the analysis, which does not ignore the importance of other publications and other content from other social networks. Thus, the collected publications fall into the following formats:

(a) - Unique graphic photo/art - unique image or graphic art, published with or without caption;

(b) - Video - video of up to one minute and/or larger videos published on IGTV;

(c) - Collection of images/graphic arts - group of two or more photos and/or images with graphic art published in a single post (Instagram allows a total of up to ten photos).

As for categorization, the work seeks to synthesize the five major areas of the election campaign with their respective subcategories. To reach these categories, both campaigns were observed in a pre-analysis and we sought to exhaust the bottleneck of the categories, understanding that a smaller number of categories offer greater analytical rigour (Bardin, 2011). However, the subcategories were maintained in order to provide quantitative data of significant value for some relevant information. The analysis categories adopted are:

(1) Candidate Image: Brazilian presidentialism tends to strengthen the profile of markedly personalist elections. Limongi and Figueiredo (1998) argue that the personalist character of the Brazilian presidentialism implies, even, a governance to the taste of the popularity of the ruler, which weakens institutional parameters. Leal (2012) discusses the personalization of the Brazilian campaigns by establishing a comparison with American elections. In this sense, recent work indicates a strong call to build the image of the candidate, who receives the nominal vote of the voters. However, the image of a candidate is not unrelated to the nature of the electoral process, since it is necessary to offer the voter information about the possible elected. Nevertheless, the mediatization of campaigns has increasingly conferred personalist tones to the parties. Therefore, we proposed as subcategories: (a) personal assignments: when the focus is on personalist aspects of the candidate and not on specific qualifications for the position; (b) political attributions: when the approach takes place on administrative characteristics, political history or general ideological positioning.

(2) Supporters: showing support is a strategy to add new groups through association with known figures, as well as to enhance the strength of the candidacy as an aggregator of popular strength. The subcategories include: a) political leadership; (b) artists and public figures and (c) popular support.

(3) Attacks: attack is a common strategy in election campaigns. This category, moreover, is fundamental to understand the polarization scenario, which is intensified with the evidence of differences and the pointing of weaknesses of the opponents. Borba (2015), in reference to negative advertising in the election period, argues that it has a useful character to the voter, because it can bring hidden facts of his knowledge. A relevant fact is present in the construction of subcategories: attacks were not limited among candidates competing for the position. They went further and involved other entities directly or indirectly linked to them. Thus, as subcategories, it is pointed out: (a) attack on the opponent: specific criticism of the opponent in the dispute; (b) attack on the party: negative point to the party and/or coalition of the opponent, with an exclusive focus on the legend and its political past; (c) attack on the figure linked to the candidate: negative association or direct attack on the figure who has a link to the competing candidate; (d) attack on other groups and/or institutions: in a polarized scenario, ideological attack on groups, social movements and actors constitutes a campaign strategy.

(4) Government Plan: one of the central objectives of the election campaigns is to allow the voter access to proposals contained in candidates' government plan. Although this item is often subdued in many campaigns, it is one of the topics that makes up communication strategies. The subcategories listed are: (a) social themes: they are governmental areas addressed specifically with regard to public policies; (b) menu: publication with various proposals from different areas; (c) comparison of proposals: induction to the comparison between ideas and projects of different applications.

(5) Mobilization: social networks allow real-time and large-scale interactivity, this was not the case on television most high-prominence campaigns, for example. Thus, the online mobilization of voters, as well as the constant updating of the campaign climate become fundamental aspects of the candidates' communication strategies. Mobilization was identified in the following subcategories: (a) voter appeal: include electoral research data, donation requests, campaigns to turn the vote and profile data on social networks, evidencing the strength of the candidacy; (b) campaign appeal: include coverage of the candidate's campaign activities and agenda. 
Table 1. Categorization of Jair Bolsonaro's (PSL) posts on Instagram

\begin{tabular}{|ccc|}
\hline Candidate's Image & Personal Assignments & 11 \\
\hline Supporters & Policy Allocations & 3 \\
& Political Leadership & 9 \\
& Public Artists And Figures & 5 \\
\hline Attacks & Popular Support / Social Groups & 11 \\
& Attack On The Adversary & 22 \\
& Attack On The Party & 2 \\
& Attack On The Candidate's Figure & 2 \\
\hline Government Plan & Attacks On Other Groups And / Or Institutions & 1 \\
& Health & 4 \\
& Education & 0 \\
& Economy & 2 \\
& Culture & 0 \\
& Public Security & 1 \\
& Housing & 2 \\
& Ministries & 3 \\
& Turism & 2 \\
& Comparison Of Proposals & 2 \\
& Regional Development & 2 \\
& Foreign Policy & 1 \\
\hline Total Publications & Public Administration & 1 \\
\hline
\end{tabular}

Discription: Table list in the quantitative plane categories triggered by the candidate Jair Bolsonaro on Instagram.

Table 2.Categorization of Fernando Haddad's (PT) posts on Instagram

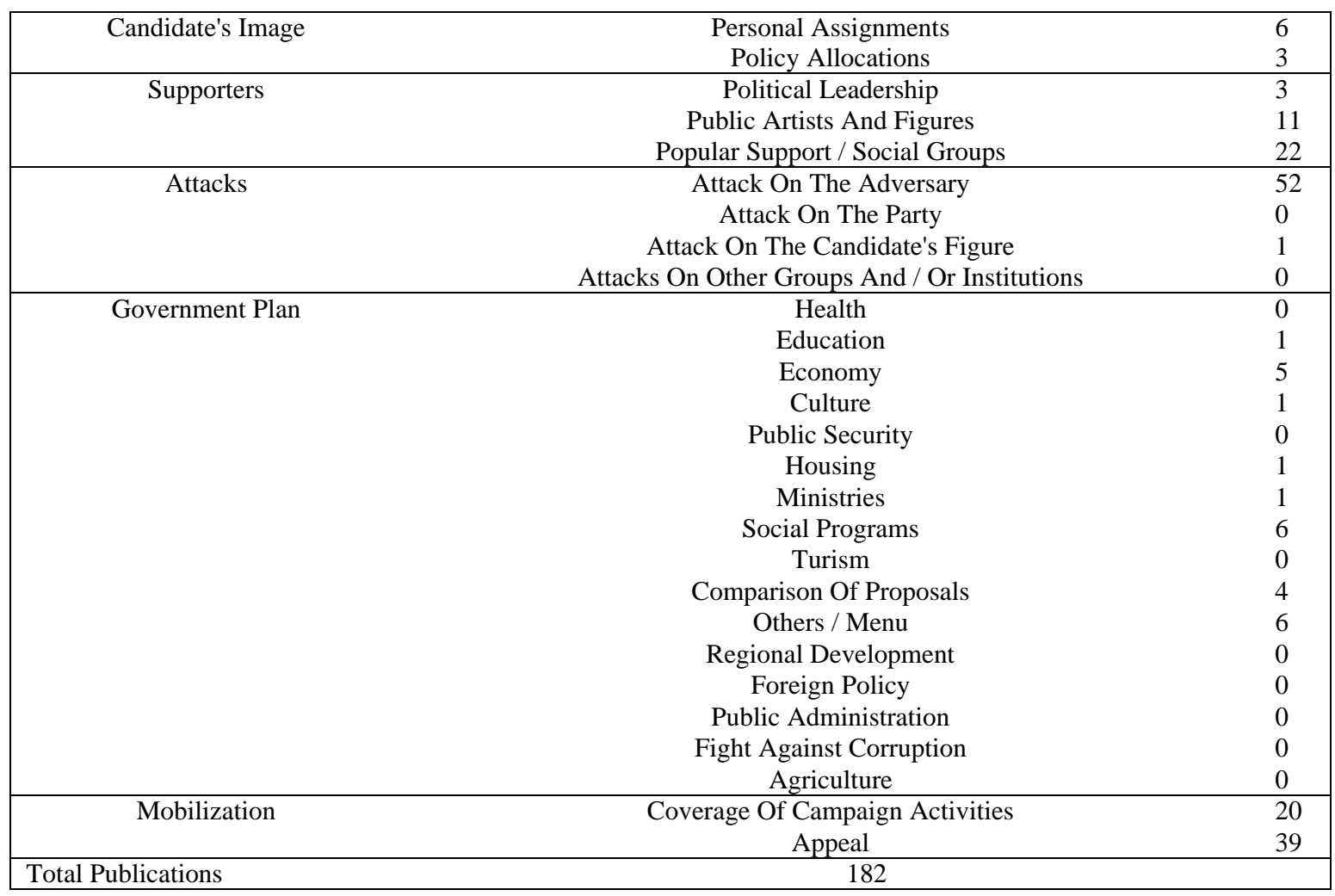

Discription:Table list in the quantitative plane categories triggered by the candidate Fernando Haddad on Instagram. 


\section{Results}

4.1Instagram Analysis of Candidate Bolsonaro: The Image of the Hero Marching Against the Worst evil of Petism

Bolsonaro's Instagram posts were mostly focused on the Attack category. The objective of the narrative, articulated with those undertaken in the others, was to establish a Manichean scenario: the struggle for good, represented by the candidacy of captain Bolsonaro, against evil, materialized in PT followers.

The ideological polarization marks the construction of the campaign, since the focus of criticism is not to the person of the opponent, Haddad, but his party and, together, the whole left. The PSL candidate's campaign uses more than half of the attack posts to disqualify PT Party, associating it, in some cases, with other left-wing parties, such as the Communist Party of Brazil (PC do B) and the Socialism and Freedom Party (PSOL).

The use of harsh words, including unusual name-calling in formal communications, marks the tone of war and threat that represents the possible turn of the left: defense of criminals, corruption, threat to democracy, opposition to moral and conservative values, translated as a threat to the family. In this sense, polarization is evidenced in differentiation: Bolsonaro is the extreme opposite of the enemy that seeks to build.

This portrait is not a simple campaign strategy, but evokes the construction of anti-petism within the Brazilian society from the most striking facts of the recent historical period. The June 2013 demonstrations followed by the unfolding and media coverage of Operation Carwash (Operação Lava Jato), culminating in the erosion of the government of Dilma Rousseff and her impeachment, helped to associate the party with corruption and a high rate of rejection (Souza,2016; Miguel, 2019).

Bolsonaro takes advantage of this sedimented image and stands as the only one capable of fighting it, especially in a second-round electoral conjuncture, when the choice of the citizen is limited between two candidacies. To do so, it is better to explain the differences, especially if the opponent is understood as the representation of the greater evil, than the focus on consensus proposals.

The other categories appear similarly in the scope of the corpus of this analysis. Government Plan (24), Supporters (18), Mobilization (17) and Candidate Image (14) are categories triggered very similarly at the quantity level. They also fulfill the function of a polarized scenario and serve the narrative of clash.

Supporters are presented as militants of a spontaneous movement of society. The vast majority of demonstrations take place through artists and popular figures and actions of voters. Although the candidate also has support from political leaders, the campaign wants to highlight Bolsonaro as the precursor of a new policy which, in addition to defeating the Left, it wants to debunk the so-called vices of political patronism and the links of corruption.

The Mobilization presents the campaign activities, restricted to punctual visits, since the candidate limited his public appearances due to the recovery of the attack suffered in the first round. The campaign, however, while exploiting the candidate's physical fragility, also evokes the strength of the candidacy with prominent publications to expressive numbers achieved on social networks. Opportunity to mobilize the electorate.

The Government Plan is shown to be very synthetic and sporadic. Most publications compare what Bolsonaro wants to undertakein contrast to what the other application presents. As an example, we can cite proposals that are elected as opposition to the Haddad's government program in publication on October 10, 2018: "zero tolerance to crime"; "stop praising communist murderous dictatorships"; "arrest and leave in jail those who have committed crimes";"against any kind of social control of the media".

The simple tone adopted seeks immediate contact with the voter, especially considering the fugacity of Instagram, but it also establishes a language proper to the campaign of clash: Bolsonaro does not need to explain a program, because it is given that his mission is to defeat the opponent. Therefore, elucidating ideological postures or programmatic replaces the parameter of presenting plans for governance. It is interesting to show a candidate tolerance to violence, even if no strategies are presented to combat them.

The Candidate's Image is ambiguous in some aspects, although both serve the strategies of the narrative, which is stable to the markedly polarized goal. Bolsonaro is built under two demarcated characters: the victim and the combatant. As a victim, his post-attack frailty is exploited. However, it is also shown how the combatant, who wrapped in militarism, assumes the messianic role of defeating the Left. It is the link between the weakness that generates commotion and the strength necessary to overcome a constituted enemy. Allocated to the narrative of frailty is the simple and common man, that ignores the scope of the traditional politician and presents himself, in general, in scenarios of his residence at will. To consolidate this analysis, we propose a general table (Table 3) with the narratives and strategies undertaken to reinforce them, in order to highlight the polarization scenario. 
Table 3. Predominant narrative vs. Campaign strategy

\begin{tabular}{|c|c|c|}
\hline Category & Predominant Narrative & Campaign Strategy \\
\hline Candidate's Image & $\begin{array}{l}\text { Victim: simple man, victimized by an } \\
\text { attack and little use to the establishment. } \\
\text { Hero: captain able to lead the movement of } \\
\text { the good citizens of the country in the } \\
\text { destruction of the nation's greatest enemy. }\end{array}$ & $\begin{array}{l}\text { Interim representations of the candidate's backstage in } \\
\text { recovering from an attack that, even weakened, } \\
\text { undertakes his dichotomous struggle in favor of the } \\
\text { Brazilians against the left, with the image of man } \\
\text { invested in heroism. It calls therefore for primary } \\
\text { identification and the commotion of war. }\end{array}$ \\
\hline Supporters & $\begin{array}{l}\text { Candidate who receives spontaneous visits } \\
\text { from friends and who is more connected to } \\
\text { popular support than to traditional } \\
\text { politicians. }\end{array}$ & $\begin{array}{l}\text { Present a spontaneous and aesthetically disorganized } \\
\text { campaign, reinforcing an anti-system pattern and } \\
\text { different from what is practiced so far in politics. }\end{array}$ \\
\hline Attacks & $\begin{array}{l}\text { Opponent is PT party, which is a collective } \\
\text { of criminals and a threat to the country if it } \\
\text { returns to power. }\end{array}$ & $\begin{array}{l}\text { Use manichaeism in order to undertake a narrative of } \\
\text { dispute and put himself in the field of the force of } \\
\text { good, which must prevail against the greatest evil. }\end{array}$ \\
\hline Government Plan & $\begin{array}{l}\text { Opposition to crime and the moral and } \\
\text { strategic postures of the opponent - denial } \\
\text { of the other and what he represents. }\end{array}$ & $\begin{array}{l}\text { Appeal to moral values as inducers of the vote without } \\
\text { the need to explain the proposals or programs. }\end{array}$ \\
\hline Mobilization & $\begin{array}{l}\text { Candidate who grows towards victory and } \\
\text { who is free from any tie with the system, } \\
\text { given the simplicity of his campaign, } \\
\text { which is done with the role of the voter, } \\
\text { especially in networks. }\end{array}$ & $\begin{array}{l}\text { Appeal to the feeling of change and adhesion to the } \\
\text { movement of defeating the greatest evil. }\end{array}$ \\
\hline
\end{tabular}

Description: Table that shows the polarization scenario between the predominant narrative and the campaign strategy of candidate Jair Bolsonaro on Instagram

\subsection{The Instagram Analysis of Candidate Haddad: The Construction of the Democrat's Image in Light of Authoritarianism}

The posts on Haddad's Instagram were mostly focused on the Mobilization category. It can be assumed that the recurrence of this narrative that seeks to mobilize voters is motivated by the polls of voting intention, who pointed to Bolsonaro ahead of the PT candidate. Thus, it was necessary to mobilize the electorate to win undecided votes. It is important to note that, although the Mobilization category appears ahead, the category that refers to the Attack is also very triggered, with almost the same number of posts.

Fernando Haddad's campaign uses an attack aimed at the figure of Jair Bolsonaro and not at the political party, differentiating himself from the strategy of his opponent who, for many times, made the attack directed at PT.From Leal's (2012) perspective, the loss of ideological references of the parties contributes to focus the discussions on the supposed qualities of the candidates and for short-term factors. Competence, integrity, decision-making capacity, charisma and personal attributes (appearance, age, religion, health, etc.)fill the space left vacant by the political discussion, especially in disputes with not very different ideologies. Although the dispute between Bolsonaro and Haddad have distinct and clear ideologies, because of Bolsonaro's political career to count on many changes of political parties, the attack on the figure of Bolsonaro and not at the party was more strategic, especially in view of the controversies surrounding his image.

The analysis made it possible to realize that the tone of the attacks, with the use of harsher words, increased during the second round campaign. Speeches such as: "bad soldier", or even less direct speeches that claimed that a candidate who does not debate ideasand does not present proposals could not be a good president. Thus, polarization is evidenced: the candidate who has no proposals, an authoritarian candidate versus a government that would be the continuation of the PT governments, portrayed as governments investing in social programs, high in the Brazilian economy, a new "Lula" government.

Haddad uses the controversial speeches constructed during Bolsonaro's political career strategically. On the other hand, Haddad stands as the candidate capable of taking the country out of the crisis, rescuing data and public policies from the last PT governments, especially Lula's government. Thus, Haddad seeks to portray Bolsonaro as an authoritarian figure, polemic, incompetent as a politician, in view of the few projects presented during the 27 years he served as a federal deputy. Haddad's image, on the other hand, is built as a continuity of PT governments.

The categories appear as follows: Supporters (36), Attacks (53) Mobilization (59), Government Plan (25) and Candidate Image (9).As already observed, the categories of attack and mobilization are the ones that appear the most. However, the others are also triggered in order to reinforce the polarization and intensification of attacks between the candidates. 
Most of the supporters presented during the campaign are popular figures, who criticize the other candidates stances and recall the good times that the country lived in PT governments; actions of voters, as in the case of the movement "turns votes", in which voters set out to talk to people in the streets in order to convince them; and another percentage of supporters are artists and popular figures.

The Mobilization presents the campaign activities, demonstrations and convening acts that showed support for Haddad and the fear of a possible election of Bolsonaro, which motivated many demonstrations. The demonstration of "Women against Bolsonaro" gained some prominence during the campaign. Once again, the intention was to reinforce political polarization at that time.

The Government Plan has little prominence during the campaign. The few posts related to this theme appear in a very generic way. In addition, sometimes the campaign sought to compare government plans of both candidates, putting Bolsonaro in a negative position, representing retrogression and authoritarianism, as well as losses of rights and investments in education, health and social policies.

In view of the polarization of the campaigns, both candidates did not show concern in presenting proposals, but in defeating the opposing candidate, as Santos (2020) pointed out as a consequence of very polarized disputes. Haddad's campaign, at times, even had some concern in presenting the government plan, highlighting education, health and social programs that often appeared in the format of menu, proposals for the different ministries were presented together. However, such proposals had a shorter time compared to the investment in the deconstruction of the image of the opponent. We observed that the main concern was to attack the figure of Bolsonaro and remember the deeds of Haddad as mayor, as well as the achievements of the PT government, reinforcing the idea that they would have two sides and the voter should choose one.

The Candidate Image is constructed as follows: the teacher. The figure of Professor Haddad is much explored, especially for the empathy that the profession arouses. This image has been reinforced all along, so much so that voters requested to vote with a book in their hands. To reinforce this image, the campaign uses his political career, while he was Minister of Education of Lula's government and when he was mayor of São Paulo city.

To facilitate the understanding of the analysis, we propose a general table (Table 4), with the narratives and strategies undertaken to reinforce them, in order to highlight the polarization scenario.

Table 4.Predominant narrative vs. Campaign strategy

\begin{tabular}{ll}
\hline Category & \multicolumn{1}{c}{ Predominant Narrative } \\
\hline Candidate's Image & Teacher: educator who fights with a book \\
& in his hand and not a weapon, someone \\
& who prioritizes education and social \\
& policies. A Democrat against an \\
& authoritarian.
\end{tabular}

Supporters

(1)

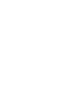

Candidate who has the support of
popular, especially the northeasterners
and the humblest, as well as the support
of artists and public figures.

\begin{tabular}{ll}
\hline Attacks & Opponent is the person of Jair Bolsonaro, \\
who is an authoritarian and threatens the \\
country to an undemocratic setback, with \\
loss of investments in social sectors.
\end{tabular}

\begin{tabular}{ll}
\hline Government Plan & $\begin{array}{l}\text { Opposition to authoritarianism and the } \\
\text { moral and strategic postures of the } \\
\text { opponent. Back of PT governments and } \\
\text { everything former president Lula } \\
\text { represents. }\end{array}$ \\
\hline Mobilization & $\begin{array}{l}\text { Candidate who fights against everything } \\
\text { Bolsonaro stands for. It grows in the polls } \\
\text { and relies on the voter to turn the votes } \\
\text { and gain the undecided voters. }\end{array}$ \\
\hline
\end{tabular}

\section{Campaign Strategy}

It intersperses his teaching position with his personal

life, emphasizing his successful marriage. The campaign reinforces his fight against authoritarianism and the neoliberal politics of the opponent. He presents himself as a kind, supportive man who defends and respects diversity. It therefore calls for empathy for the teacher and for the achievements of PT governments, especially in education.

Present an organized campaign, with testimony of popular who were benefited by PT governments and/or repudiates the position of the opposition candidate. As well as demonstrating the support of prominent artists and public figures in Brazilian society.

It uses a narrative of dispute, placing itself in the field of the force of good, which must prevail against the greater evil. The teacher, democrat, solidary against the military, authoritarian, controversial that does not respect diversity.

Appeal to values like respect and empathy. Investment proposals in education, health and social programs stand out more than others. More minority-oriented government plan.

Appeal to the undecided electorate and to voters who are against the authoritarian, reckless and disrespectful positions of the other candidate. Strong appeal to minorities. 
Description: Table that shows the polarization scenario between the predominant narrative and the campaign strategy of candidate Fernando Haddad on Instagram

\section{Discussion}

Before starting the discussion about the polarization process, it is important to highlight what precedes this processand discuss how this also happens with voters. According to Borges and Vidigal (2018), social and political behavior is directly related to the behavior of groups. Thus, it is evident that party identification is related to a type of social identity. This social identity can be lost when the main political parties converge on their positions or adopt policies that do not match their usual or even ideological agenda (Lupo, 2014).

Thus, voters are unable to differentiate the parties, hindering the process of polarization. In Brazilian case, where the redemocratization is recent and the parties of the so-called "Centrão" (something like "The Center") never had much prominence in the elections; this loss of identification is not noticeable. It can be said that in elections prior to 2014 the polarization took place, maintaining a level of argumentative debate between PT versus PSDB. In 2018, there was a fiercer and more polarized dispute, weakening political discussions, which led to a much more personalist confrontation focusing on attacks on candidates.

However, in an electoral dispute in which candidates are ideologically in extreme positions (right versus center-left),voters are more encouraged, not only by identifying with their group, but also to disagree with social groups considered as opposing groups (Borges, Vidigal; 2018). The way the political dispute took place in 2018, where two extremes were seen: left and right; the teacher and the military; conservative and liberal, affected the strength and stability of party preferences. A polarized electoral contest, in which parties and candidates defend very different positions, increases the likelihood of voter identification. The use of networks also contributes to this ideological dispute among voters, from the moment you select the identification groups (the so-called digital bubble), making clear a membership of a specific group, leading the voter to a clearer perception. However, the increase in polarization has also contradictorily generated a greater fragility of the political debate, since the dispute became much more passionate. Instead of debating political issues for the country, the candidates focused on personal attacks, configuringone of the most aggressive elections in terms of propaganda.

It is too early to say that the polarized electoral process of 2018 has strengthened or weakened the parties, because one should also consider the expressive electorate that annulled or justified the vote. On the other hand, one should only talk about mass polarization when you have well-positioned voters at both extremes and when there is a considerable reduction in centrist candidacies, however much the PSL and PT occupied the largest number of benches in the House of Representatives, the centre parties also exert great influence on national politics and have managed to elect a considerable number of candidates. Moreover, the fact that they had 30 parties with representativeness in Congress leads to a strong fragmentation, which constituted a serious obstacle to coalition presidentialism.

However, if on one hand we cannot say that there is, in fact, a polarization on the part of the electorate, the analysis proved that there is a polarization on the part of the presidential candidates. The analysis serves polarization identification parameters as a series of more objective data that differentiate applications and their narratives. To this end, we propose a framework with the main ideological differentiations with regard to the Left and Right approach by the view of political scientist Norbet Bobbio (1995).

Before explaining the general lines about the author's view of these fields, it is worth noting that the positioning of the political parties is not always openly placed at one of the divergent points of a political spectrum. Downs (1957) argues that there may be transition according to electoral interests. According to the author, because the conquest of power is the greatest reason for the existence of the parties, they tend to adjust their discourses according to the moment and demand.

In this sense, we observed the existence of "catch all" parties, that is, those which seek to potentiate the conquest of votes trying to capture the attention and interest of the entire mass of voters - so their narratives converge to the center and allow associations both with the Left and the Right. The term, drafted by Kircheimer (2012), points to the centripetal trend of major parties, especially in the majority of electoral races.

However, the 2018 presidential campaign showed another trend: the explicitness of divergences through ideological affirmation. We therefore use the concept of Left and Right without ignoring that it is polysemic. Bobbio (1995) constitutes a more objective view on Left and Right through the pillars of equality-inequality. The perception of the nature of both differs in each axis and provides a differentiated role in the treatment of social problems. The left understands inequality to be a social phenomenon which is, therefore, eliminable. The right, on the other hand, understands inequalities to be natural and, therefore, impossible to be eliminated. 
Other points raised by the author are observed in the narratives of candidates Bolsonaro (PSL) and Haddad (PT), that turn the electoral game into a plebiscite between two majority chains. Although some publications point to standardization of some more controversial discourses, that can be identified as a tendency to the center, the great narrative preserves itself objectively demarcated in an ideological territory. Table 5 shows ideological approaches from five points of identification.

Table 5.Ideological Identification Points - Bolsonarovs. Haddad

\begin{tabular}{ccc}
\hline Ideological Identification & Bolsonaro & Haddad \\
\hline Economy & Liberalisation of the economy & Investment in Internal Market and state defense \\
\hline Religion & Defense of Christian values & Respect for religious diversity \\
\hline Moral Themes & $\begin{array}{c}\text { Defending order, rejecting the } \\
\text { approach of minorities, against } \\
\text { abortion }\end{array}$ & $\begin{array}{c}\text { Defense of diversity, democratic institutions, } \\
\text { public policies aimed at minorities }\end{array}$ \\
\hline Identification & Militarism & Teachers / Education \\
\hline Opposition & To socialism/communism & To authoritarianism / fascism
\end{tabular}

Descriptions: summarizes the political views demarcated in the analyzed publications.

They therefore elucidate the position on the left and right of the applications. The points observed by Bolsonaro's narrative identify him to the right of the political spectrum, while the same occurs with Haddad on the left.

Although the focus of this work is the observation of the narrative of polarization, it fulfills an addendum to the electoral result. In 2018, there was a large portion of the electorate that did not adhere to this polarization, opting for the white or null vote. There was also a higher average of abstentions than in previous elections.

\section{Conclusion}

The social networks played a prominent role in the narrative dispute during the 2018 election campaign. The increase in political polarization guided, above all, by the ideological intensification between right and left, in addition to the emergence of new electoral rules and the reduction of the time of election advertising on radio and television, allowed the rise of multiple digital platforms, including Instagram.

In the electoral context, the social networks operated with a space of dialogue and convincing between politicians on the campaign trail and voters, in view of the ability to circumvent the mechanisms of intermediation of traditional media. In this context, it was possible to observe that Instagram was used by candidates to mobilize recurring themes of election campaigns, but in a very strategic way. The candidate Bolsonaro (PSL) sought the attack category to win voter support, insofar as he dislikes the Workers Party and former President Lula (PT) became an election flag. The candidate used the category image to approach the figure of the savior of the messianic homeland and presented himself as the only one capable of saving the country of communism and the risks of PT to return to power. There is, in Bolsonaro's publications, a synchronous narrative that relies on anti-petism to sensitize the voter.

The candidate Fernando Haddad (PT), in a similar way, sought to rely on the category attack to warn the voter about the risks of his opponent. He evoked Bolsonaro's homophobic and racist discourse and sought the rhetoric of the opponent's political unpreparednessto convince the voter that it would be the best option for the country. During the campaign, Haddad had to face the dubiousness of having Lula as his mentor. To the extent that Haddad used the figure of former President Lula, gained the sympathy of voters and supporters to Lulismo, but boosted Bolsonaro's campaign, further expanding his rejection. Finally, the candidate Haddad ended up defeated by the Manichaeism that established himself in the figure of antilulism and antipetism, since political polarization has found, in social networks, a space for the construction and propagation of such narratives.

\section{References}

Albuquerque, A. de. (1999). 'Aqui você vê a verdade na tevê'. A propaganda política na televisão. Mestrado: Universidade Federal Fluminense, Niterói. 204.

Bardin, L. (2011). Análise de conteúdo. São Paulo, SP: Edições 70.

Bobbio, N. (1995). Direita e esquerda: razões e significados de uma distinção política. São Paulo, SP: Unesp.

Borba, F. (2015). Propaganda negativa nas eleições presidenciais brasileiras. Opinião Pública, 21(2), 268-295. https://doi.org/10.1590/1807-01912015212268

Borges, A., \& Vidigal, R. (2018). Do lulismo ao antipetismo? Polarização, partidarismo e voto nas eleições presidenciais brasileiras. Opinião Pública, 24(1), 54-89. https://doi.org/10.1590/1807-0191201824153 
Braga, S., \& Carlomagno, M. (2018). Elections as usual? longitudinal analysis of the changes caused by digital technologies in Brazilian electoral campaigns (1998-2016). Rev. Bras. Ciênc. Polit. [online], 26, 7-62. https://doi.org/10.1590/0103-335220182601

Carlón, M. (2016). Apropriacion contemporánea de la teoria comunicacional de Eliseo Verón In E. Vizer, C. Vidales. (Coords). Comunicación, campo(s) teorias y problemas - Una perspectiva Internacional (pp. 125-154). Salamanca, Espanha: Editorial Comunicación Social.

Datafolha: how many voters for each candidate use social media, read and share political news (2018, October). Retrieved February, 19, 2020, from https://g1.globo.com/politica/eleicoes/2018/eleicao-em-numeros/noticia/2018/10/03/datafolha-quantos-eleitores-de -cada-candidato-usam-redes-sociais-leem-e-compartilham-noticias-sobre-politica.ghtml

Downs, A. (1957). An economic theory of democracy. New York, EUA: Harper \& Row.

Egler, T. T. C. (2010). Redes tecnossociais e democratização das políticas públicas. Sociologias, 23, 208-236. https://doi.org/10.1590/S1517-45222010000100008

Exame. Estes são os dez países que mais usam o Instagram. (2019, May). Retrieved February, 20, 2002, from https://exame.com/tecnologia/estes-sao-os-dez-paises-que-mais-usam-o-instagram/

Figueiredo, M., Bezerra, H. D., Aldé, A., \& Jorge, V. L. (1998). Estratégias de persuasão em eleições majoritárias: uma proposta metodológica para o estudo da propaganda eleitoral. Opinião Pública, 4(3), 182-203. https://www.cesop.unicamp.br/vw/1IEnHMDM_MDA_e418a_/v4n3a02.pdf

Gomes, W. (2004). As transformações da política na era da comunicação de massa. São Paulo, SP: Paulus.

Gomes, W., Fernandes, B., Reis, L., \& Silva, T. (2009). "Politics 2.0" A Campanha on-line de Barack Obama em 2002. In XVIII Encontro da Compós [online], Belo Horizonte, Brasil, pp.1-27. Retrieved January 10, 2020, from http://www.compos.org.br/data/biblioteca_1074.pdf

Hjarvard, S. (2012). Midiatização: teorizando a mídia como agente de mudança social e cultural. Matrizes, 5(3), 53-91. https://doi.org/10.11606/issn.1982-8160.v5i2p53-91

Hollanda, A. F. B. de., \& Jesus, D. S. V. de. (2018). 'João Trabalhador Criativo'? A economia criativa nas postagens do prefeito João Doria Jr. no Instagram. Revista Compolítica, 8(2), 101-123. https://doi.org/10.21878/compolitica.2018.8.2.159

Howard, P. N. (2006). New Media Campaigns and the Managed Citzen. Cambridge: Cambridge University Press. https://doi.org/10.1017/CBO9780511615986

Iasulaitis, S., \& Nebot, C. P. (2015). Campanhas Políticas na Internet: Novas Tendências de Comunicação Eleitoral. In Congresso Internacional de Comunicación Política y Estrategias de Campaña (Alice), [online]. Buenos Aires, Argentina, pp. 1-26. Retrieved January 5, 2020, from http://www.alice-comunicacionpolitica.com/abrir-ponencia.php?f=0dae0020202e8641e36ab79dc1a0cf6a.pdf

Ituassu, A., Lifschitz, S., Capone, L., \& Mannheimer, V. (2019). De Donald Trump a Jair Bolsonaro: democracia e comunicação política digital nas eleições de 2016, nos Estados Unidos, e 2018, no Brasil. In $8^{\circ}$ Congresso da Associação Brasileira de Pesquisadores em Comunicação e Política [online]. Brasília, Brasil, pp. 1-25. Retrieved January 8, 2020 from http://ctpol.unb.br/compolitica2019/GT4/gt4_Ituassu_et_al.pdf

Kirchheimer, O. (2012). A transformação dos sistemas partidários da Europa Ocidental. Revista Brasileira de Ciência Política, 7, 349-385. https://doi.org/10.1590/S0103-33522012000100014

Leal, P. R. F. (2012). Os riscos do personalismo na política. Revista de Jornalismo Científico e Cultural da Universidade Federal de Juiz de Fora. Juiz de Fora, MG: Ed. da UFJF.

Lemos, A., \& Lévy, P. (2010). O futuro da internet: em direção a uma ciberdemocracia planetária. São Paulo, SP: Paulus.

Levitsky, S., \& Ziblatt, D. (2018). Como as democracias morrem. Rio de Janeiro, RJ: Editora Zahar.

Limongi, F., \& Figueiredo, A. (1998). Bases institucionais do presidencialismo de coalizão. Lua Nova: Revista de Cultura e Política, 44, 81-106. https://doi.org/10.1590/S0102-64451998000200005

Lupo, N. (2014). Party brands and partisanship: theory with evidence from a survey experiment in Argentina. American Journal of Political Science, 57(1), 49-64. https://doi.org/10.1111/j.1540-5907.2012.00615.x

Miguel, L. F. (2019). O colapso da democracia no Brasil: da constituição ao golpe de 2016. São Paulo, SP: Fundação Rosa Luxemburgo. 
Oliveira, L. A. (2004). As estratégias retóricas na construção dos mundos de natureza ficcional da política. Um estudo comparativo das campanhas de Belo Horizonte e Salvador na eleição municipal de 2000-2004. Rio de Janeiro: Instituto Universitário de Pesquisas do Rio de Janeiro.

Santos, D. L. V. (2020). O fim da polarização PT versus PSDB em Minas Gerais: uma análise das campanhas eleitorais no Facebook e Horário Eleitoral dos principais candidatos ao governo de Minas Gerais em 2018. Mestrado: Universidade Federal de Juiz de Fora. 167p.

Social Medias at 2018 elections (2018, October). Retrieved from https://observa2018.com.br/wp-content/uploads/2018/12/Policy-Paper-1-PORT-Artigo-Conceitual-1.pdf

Souza, J. (2016). A radiografia do golpe: entenda como e por que você foi enganado. Rio de Janeiro, RJ: LeYa.

Vèron, E. (1997). Esquema para el análisis de la mediatización. Revista Diálogos de la comunicación, 48, 9-16. Retrieved from https://comycult.files.wordpress.com/2014/04/veron_esquema_para_el_analisis_de_la_mediatizacion.pdf

Wolf, M. (1999). Teorias da comunicação. Lisboa: Editorial Presença.

\section{Copyrights}

Copyright for this article is retained by the author(s), with first publication rights granted to the journal.

This is an open-access article distributed under the terms and conditions of the Creative Commons Attribution license which permits unrestricted use, distribution, and reproduction in any medium, provided the original work is properly cited. 